\title{
Alzheimer's disease and infections, where we stand and where we go
}

\author{
Roberto Monastero $^{1 *}$, Calogero Caruso ${ }^{2}$ and Sonya Vasto 3,4
}

\section{Editorial}

Alzheimer's disease (AD) is a progressive neurological disorder, which represents the most common form of dementia, one of the major causes of disability in later life. Age is the greatest risk factor for $\mathrm{AD}$, which typically affects people aged 65 years and over, with an age-standardised prevalence of 4.4 [1]. However, $\mathrm{AD}$ is not a normal part of ageing and advanced age alone does not justify the disease. Several pathways have been implicated in AD pathophysiology, the most described is the neurodegenerative one, which lead to the brain accumulation of beta-amyloid and neurofibrillary tangles, aggregations of hyperphosphorylated tau protein, macroscopically resulting in brain atrophy due to neuronal death [2]. These pathological hallmarks of $\mathrm{AD}$ have been recently incorporated in the new recommendations on diagnostic guidelines for $\mathrm{AD}$, which describe different stages of the disease, including its preclinical and symptomatic pre-dementia phases [3].

Genetics accounts for less than $3 \%$ of $\mathrm{AD}$, familiar $\mathrm{AD}$ at early onset, resulting from mutations in three genes, i.e. APP, PS1 and PS2. Furthermore, the Apolipoprotein E4 (ApoE4) genotype is the only, robust, susceptibility gene for $\mathrm{AD}$ [2], although meta-analysis and genome scanning have revealed several susceptibility loci with low odds ratios $[4,5]$. Overall, multiple gene-gene and environment interactions cause AD; however, various risk factors differently act throughout ageing $[2,6]$. Large data have been collected in the last two decades regarding the putative role of vascular disease, including systemic atherosclerosis, high blood pressure, diabetes, high level of cholesterol, tobacco smoking, as well as other vascular risk factors, as pathogenetic cause of $\mathrm{AD}$ [6-8]. However, a central role for systemic inflammation has been claimed also taking into account previously reported data, traumatic brain injury and oxidative stress [9-13]. Indeed, only a

\footnotetext{
* Correspondence: roberto.monastero@unipa.it

${ }^{1}$ Department of Experimental Biomedicine and Clinical Neurosciences, University of Palermo, Palermo, Italy

Full list of author information is available at the end of the article
}

small percentage of people aged 80 years or over has a pure neurodegenerative $\mathrm{AD}$, and mixed dementia with vascular and/or inflammatory components are present [14]. Peripheral inflammation is indeed present in early stage of $\mathrm{AD}$ and is higher than that observed during non-pathological ageing [13]. Moreover, an altered inflammatory regulation is also present in Mild Cognitive Impairment $(\mathrm{MCI})$, the intermediate stage between the expected cognitive decline of normal ageing and the more serious decline of dementia [15], and correlates with the progression to $\mathrm{AD}$ [13].

Accordingly, acute episodes of systemic inflammation with increased levels of inflammatory mediator tumor necrosis factor-alpha, which are associated with $\mathrm{AD}$ [5], have been shown to be associated with long-term cognitive decline in a prospective cohort study of subjects with $\mathrm{AD}$ [16]. The missing link between central neuro-inflammation and peripheral inflammatory state might be represented by infectious factors [17].

The possibility of an infectious aetiology for AD has been repeatedly proposed over the past three decades, suggesting the role of viral and bacterial chronic infections as causative inflammatory pathway for $\mathrm{AD}$. Concerning bacterial infections, data from a recent meta-analysis demonstrated that Spirochetal or Chlamydophila Pneumoniae infections were strongly associated with AD [18].

More interestingly, the role of chronic inflammation in periodontal disease (PD) has been suggested over the last decade as a potential risk factor for $\mathrm{AD}$ [17,19-21]. In particular, researchers from US found that antibody levels to specific oral pathogens were significantly increased at baseline serum draw in subjects who lately developed $\mathrm{MCI}$ or $\mathrm{AD}$, thus suggesting that PD could potentially contribute to the risk of $\mathrm{AD}$ [21]. In cases of severe $\mathrm{PD}$, pro-inflammatory molecules may induce a systemic inflammation and may, therefore, access the brain via systemic circulation. Pro-inflammatory molecules, derived locally from periodontal tissue, may stimulate trigeminal nerve fibres, leading to an increase in the number of brain cytokines. These cytokines may act on the already 
primed glial cells, resulting in an amplified reaction and possible progression of $\mathrm{AD}[18,20]$.

The concept of a viral role in $\mathrm{AD}$, specifically of herpes simplex virus type 1 (HSV-1), was first proposed several decades ago. However, it was only in 1991 that by polymerase chain reaction it was looked for HSV-1 DNA in autopsy brain specimens. In all specimens from $8 \mathrm{AD}$ patients and 6 normal individuals (from temporal, frontal and hippocampal lobes), the authors found viral sequences (22). It was postulated that factors such as number or expression of viral genes and host susceptibility might be related to incidence of $\mathrm{AD}[22,23]$.

HSV-1 is a ubiquitous virus that affects more than $80 \%$ of people over 65 worldwide. It is a neurotropic double-stranded DNA virus that primarily infects epithelial cells of oral and nasal mucosa, where virus undergoes lytic replication; the newly produced viral particles may enter sensory neurons and, by axonal transport, reach the trigeminal ganglion where they usually establish a latent infection. The trigeminal ganglion neurons also project to the trigeminal nuclei located in the brainstem. From here, neurons project to the thalamus to finally reach the sensory cortex. This is the path through which the reactivated virus may reach the central nervous system (CNS), where it may cause acute neurological disorders like encephalitis or a mild, clinically asymptomatic, infection, or establish lifelong latent infection. It has been proposed that virus is normally latent in many elderly brains but reactivates periodically, as in the peripheral nervous system, under certain conditions, for example stress, immunosuppression, and peripheral infection, causing cumulative damage and eventually development of AD $[17,23,24]$. Thus, elderly immunosenescence might be responsible for its reactivation [17]. Several epidemiological studies have shown, using serological data, an association between systemic infections and cognitive decline, with HSV1 particularly implicated $[17,24,25]$. A very recent Swedish nested case-control study showed that the presence of anti-HSV-1 IgG antibodies doubled the risk for AD in persons for whom plasma was collected more than 6.6 years before the AD diagnosis [26]. Of interest, this risk increased in subject aged over 60 years and among females. Another study from Italy reported that elevated serum HSV-1 antibody titres correlated with cortical grey matter volume [27].

It is interesting to note that other herpes viruses share the ability to become latent in the infected host and eventually latently infect neurons. However, investigations focused on different viruses of the herpes family, such as human cytomegalovirus (CMV), Epstein-Barr virus (EBV) or human herpes virus 6 (HHV-6) in $A D$ are limited [17]. A recent work showed that increased CMV antibody levels were present in the elderly who developed clinical AD during a five years follow-up [28].
In a study of deceased and autopsied subjects from a clinical-pathological community cohort, the authors found associations of CMV-related immunologic and virologic characteristics with $\mathrm{AD}$ neuropathology and additional trends toward associations with clinical diagnosis [29]. Nonetheless, these findings could equally well be explained by an indirect effect since reactivation of HSV-1 is associated with CMV and age, perhaps via CMVinduced immunosenescence [30,31]. On the other hand, a few data present in literature concerning the serological association between EBV or HHV-6 and $\mathrm{AD}$ could be explained by a similar indirect effect. Both HSV-1 reactivation and EBV and HHV-6 antibody stimulation can, in fact, be triggered by $\mathrm{T}$ immunosenescence that is stronger in AD than in control elderly [32]. As an alternative, but not mutually exclusive, possibility, EBV and HHV-6 titles might indicate a systemic inflammation responsible for HSV-1 reactivation [33].

Indeed, and as reviewed by Itzhaki [23], there is evidence for direct possible pathophysiological mechanisms in AD only for HSV-1 since reactivated HSV-1 can cause direct and inflammatory damage in CNS. Implicating HSV-1 further in AD is the discovery that HSV-1 DNA is specifically localized in amyloid plaques in AD. In addition, data by several groups show that HSV-1 infection of cells in culture causes formation of $\beta$-amiloid, datum initially found by Wozniak et al., [34] and of AD-like tau, datum initially found by Zambrano et al. [35]. Other relevant, harmful effects of infection include the following: dynamic interactions between HSV-1 and amyloid precursor protein (APP), which would affect both viral and APP transport [23].

As previously stated, findings from a genome-wide association study in a large cohort of patients with AD showed that a limited set of genes were associated with the disease [4]. Licastro and co-workers [17,36] suggest that the polymorphism association in some of these genes is consistent with a non-conventional interpretation of $\mathrm{AD}$ aetiology. These data suggest that differential genetic backgrounds in genes regulating immune defences against herpes viruses are associated with agerelated cognitive deterioration and $\mathrm{AD}$. Cycles of virus latency/infections may therefore contribute to neurodegeneration associated with $\mathrm{AD}$ in genetically predisposed elderly, leading to neuronal loss, inflammation and amyloid deposition.

However, only a few prospective cohort studies have confirmed the role of viral and bacteria infections in AD. Overall, available data suggest a link between chronic infections and increased risk for $\mathrm{AD}$, possibly through a low-grade, chronic infection and inflammation in individuals who have inherent susceptibility traits. However, the majority of researches conducted have been cross-sectional, observational studies, which 
include relatively small hospital-based samples with inherent problems of selection and residual confounding. Accordingly, further prospective, population-based studies conducted in large cohorts investigating the link between infection and $\mathrm{AD}$ are warranted, taking into account APOE typing because of its involvement both in AD and chronic infections $[2,37,38]$. In any case, successful treatment of chronic infections is a challenging but mandatory goal to improve the quality of life in the elderly.

\section{Competing interests}

The authors declare that they have no competing interests.

\section{Authors' contributions}

RM drafted the paper. All authors edited the paper and approved its final version.

\section{Acknowledgements}

This work was supported by Grants from Palermo University to C.C. (FFR2012/2013 Role of Immune-Inflammatory Responses in Successful Ageing). We thank Professor Ruth F Itzhaki for her criticism.

\section{Author details}

${ }^{1}$ Department of Experimental Biomedicine and Clinical Neurosciences, University of Palermo, Palermo, Italy. ${ }^{2}$ Department of Pathobiology and Medical and Forensic Biotechnologies, University of Palermo, Palermo, Italy. ${ }^{3}$ National Center for Research, Institute of Biomedicine and Molecular Immunology, Palermo, Italy. ${ }^{4}$ Department of Science and Biological, Chemical and Pharmaceutical Technologies, Institute of Biomedicine and Molecular Immunology, Palermo, Italy.

Received: 8 December 2014 Accepted: 8 December 2014

Published online: 17 December 2014

\section{References}

1. Lobo A, Launer LJ, Fratiglioni L, Andersen K, Di Carlo A, Breteler MM, Copeland JR, Dartigues JF, Jagger C, Martinez-Lage J, Soininen H, Hofman A: Prevalence of dementia and major subtypes in Europe: a collaborative study of population-based cohorts. Neurologic Diseases in the Elderly Research Group. Neurology 2000, 54(11S5):S4-S9.

2. Ballard C, Gauthier S, Corbett A, Brayne C, Aarsland D, Jones E: Alzheimer's disease. Lancet 2011, 377:1019-1031.

3. Jack CR Jr, Albert MS, Knopman DS, McKhann GM, Sperling RA, Carrillo MC, Thies B, Phelps CH: Introduction to the recommendations from the National Institute on Aging-Alzheimer's Association workgroups on diagnostic guidelines for Alzheimer's disease. Alzheimers Dement 2011, 7:257-262.

4. Lambert JC, Ibrahim-Verbaas CA, Harold D, Naj AC, Sims R, Bellenguez C, DeStafano AL, Bis JC, Beecham GW, Grenier-Boley B, Russo G, Thorton-Wells TA, Jones N, Smith AV, Chouraki V, Thomas C, Ikram MA, Zelenika D, Vardarajan BN, Kamatani Y, Lin CF, Gerrish A, Schmidt H, Kunkle B, Dunstan ML, Ruiz A, Bihoreau MT, Choi SH, Reitz C, Pasquier F, et al: Meta-analysis of 74,046 individuals identifies 11 new susceptibility loci for Alzheimer's disease. Nat Genet 2013, 45:1452-1458.

5. Di Bona D, Candore G, Franceschi C, Licastro F, Colonna-Romano G, Cammà C, Lio D, Caruso C: Systematic review by meta-analyses on the possible role of TNF-alpha polymorphisms in association with Alzheimer's disease. Brain Res Rev 2009, 61:60-68.

6. Licastro F, Chiappelli M, Caldarera CM, Porcellini E, Carbone I, Caruso C, Lio D, Corder EH: Sharing pathogenetic mechanisms between acute myocardial infarction and Alzheimer's disease as shown by partially overlapping of gene variant profiles. J Alzheimers Dis 2011, 23:421-431.

7. Viswanathan A, Rocca WA, Tzourio C: Vascular risk factors and dementia: how to move forward? Neurology 2009, 72:368-374.

8. Accardi G, Caruso C, Colonna-Romano G, Camarda C, Monastero R, Candore $\mathrm{G}$ : Can Alzheimer disease be a form of type 3 diabetes? Rejuvenation Res 2012, 15:217-221.

9. Shively S, Scher Al, Perl DP, Diaz-Arrastia R: Dementia resulting from traumatic brain injury: what is the pathology? Arch Neurol 2012, 69:1245-1251.
10. Mangialasche F, Polidori MC, Monastero R, Ercolani S, Camarda C, Cecchetti R, Mecocci P: Biomarkers of oxidative and nitrosative damage in Alzheimer's disease and mild cognitive impairment. Ageing Res Rev 2009, 8:285-305.

11. Candore G, Bulati M, Caruso C, Castiglia L, Colonna-Romano G, Di Bona D, Duro G, Lio D, Matranga D, Pellicanò M, Rizzo C, Scapagnini G, Vasto S: Inflammation, cytokines, immune response, apolipoprotein $\mathrm{E}$, cholesterol, and oxidative stress in Alzheimer disease: therapeutic implications. Rejuvenation Res 2010, 13:301-313.

12. Latta $\mathrm{CH}$, Brothers HM, Wilcock DM. Neuroinflammation in Alzheimer's disease; A source of heterogeneity and target for personalized therapy. Neuroscience 2014, in press doi:10.1016/j.neuroscience.2014.09.061.

13. Brosseron F, Krauthausen M, Kummer M, Heneka MT: Body fluid cytokine levels in mild cognitive impairment and Alzheimer's disease: a comparative overview. Mol Neurobiol 2014, 50:534-544.

14. Fotuhi M, Hachinski V, Whitehouse PJ: Changing perspectives regarding late-life dementia. Nat Rev Neurol 2009, 5:649-658.

15. Monastero R, Mangialasche F, Camarda C, Ercolani S, Camarda R: A systematic review of neuropsychiatric symptoms in mild cognitive impairment. J Alzheimers Dis 2009, 18:11-30.

16. Holmes C, Cunningham C, Zotova E, Woolford J, Dean C, Kerr S, Culliford D, Perry VH: Systemic inflammation and disease progression in Alzheimer disease. Neurology 2009, 73:768-774.

17. Licastro F, Carbone I, Raschi E, Porcellini E. The 21st century epidemic: infections as inductors of neuro-degeneration associated with Alzheimer's Disease. Immun Ageing 2014, 11:22.

18. Maheshwari P, Eslick GD. Bacterial Infection and Alzheimer's Disease: A Meta-Analysis. J Alzheimers Dis 2015, 43:957-966.

19. Singhrao SK, Harding A, Simmons T, Robinson S, Kesavalu L, Crean S: Oral inflammation, tooth loss, risk factors, and association with progression of Alzheimer's disease. J Alzheimers Dis 2014, 42:723-737.

20. Campisi G, Chiappelli M, De Martinis M, Franco V, Ginaldi L, Guiglia R, Licastro F, Lio D: Pathophysiology of age-related diseases. Immun Ageing 2009, 6:12.

21. Sparks Stein P, Steffen MJ, Smith C, Jicha G, Ebersole JL, Abner E, Dawson D 3rd: Serum antibodies to periodontal pathogens are a risk factor for Alzheimer's disease. Alzheimers Dement 2012, 8:196-203.

22. Jamieson GA, Maitland NJ, Wilcock GK, Craske J, Itzhaki RF: Latent herpes simplex virus type 1 in normal and Alzheimer's disease brains. J Med Virol 1991, 33:224-227.

23. Itzhaki RF: Herpes simplex virus type 1 and Alzheimer's disease: increasing evidence for a major role of the virus. Front Aging Neurosci 2014, 6:202.

24. Piacentini R, De Chiara G, Li Puma DD, Ripoli C, Marcocci ME, Garaci E, Palamara AT, Grassi C: HSV-1 and Alzheimer's disease: more than a hypothesis. Front Pharmacol 2014, 5:97.

25. Letenneur L, Pérès K, Fleury H, Garrigue I, Barberger-Gateau P, Helmer C, Orgogozo JM, Gauthier S, Dartigues JF: Seropositivity to herpes simplex virus antibodies and risk of Alzheimer's disease: a population-based cohort study. PLoS One 2008, 3:e3637.

26. Lövheim H, Gilthorpe J, Johansson A, Eriksson S, Hallmans G, Elgh F. Herpes simplex infection and the risk of Alzheimer's disease-A nested case-control study. Alzheimers Dement. 2014 Oct 7. doi:10.1016/j.jalz.2014.07.157

27. Mancuso R, Baglio F, Cabinio M, Calabrese E, Hernis A, Nemni R, Clerici M: Titers of herpes simplex virus type 1 antibodies positively correlate with grey matter volumes in Alzheimer's disease. J Alzheimers Dis 2014, 38:741-745.

28. Carbone I, Lazzarotto T, lanni M, Porcellini E, Forti P, Masliah E, Gabrielli L, Licastro F: Herpes virus in Alzheimer's disease: relation to progression of the disease. Neurobiol Aging 2014, 35:122-129.

29. Lurain NS, Hanson BA, Martinson J, Leurgans SE, Landay AL, Bennett DA, Schneider JA: Virological and immunological characteristics of human cytomegalovirus infection associated with Alzheimer disease. J Infect Dis 2013, 208:564-572.

30. Stowe RP, Peek MK, Cutchin MP, Goodwin JS: Reactivation of herpes simplex virus type 1 is associated with cytomegalovirus and age. J Med Virol 2012, 84:1797-1802.

31. Itzhaki RF, Klapper P: Cytomegalovirus: an improbable cause of Alzheimer disease. J Infect Dis 2014, 209:972-973.

32. Gironi M, Borgiani B, Farina E, Mariani E, Cursano C, Alberoni M, Nemni R, Comi G, Buscema M, Furlan R, Grossi E: A Global Immune Deficit in Alzheimer's Disease and Mild Cognitive Impairment Disclosed by a Novel Data Mining Process. J Alzheimers Dis 2014, in press, doi:10.3233/ JAD-141116. 
33. Itzhaki RF, Dobson CB: Alzheimer's disease and herpes. CMAJ 2002, 167:13.

34. Wozniak MA, Itzhaki RF, Shipley SJ, Dobson CB: Herpes simplex virus infection causes cellular beta-amyloid accumulation and secretase upregulation. Neurosci Lett 2007, 429:95-100.

35. Zambrano A, Solis L, Salvadores N, Cortés M, Lerchundi R, Otth C: Neuronal cytoskeletal dynamic modification and neurodegeneration induced by infection with herpes simplex virus type 1. J Alzheimers Dis 2008, 14:259-269.

36. Porcellini E, Carbone I, lanni M, Licastro F: Alzheimer's disease gene signature says: beware of brain viral infections. Immun Ageing 2010, 7:16

37. Chiba-Falek O, Linnertz C, Guyton J, Gardner SD, Roses AD, McCarthy JJ, Patel K: Pleiotropyand allelic heterogeneity in the TOMM40-APOE genomic region related to clinical and metabolic features of hepatitis $C$ infection. Hum Genet 2012, 131:1911-1920.

38. Wozniak M, Itzhaki RF: Apolipoprotein E: Microbial Friend or foe? In LR Penfield and RT Nelson. Edited by Research A. Inc: Nova; 2009:99-112.

\section{Submit your next manuscript to BioMed Central and take full advantage of:}

- Convenient online submission

- Thorough peer review

- No space constraints or color figure charges

- Immediate publication on acceptance

- Inclusion in PubMed, CAS, Scopus and Google Scholar

- Research which is freely available for redistribution 